\title{
Pengembangan Sumber Belajar Tes dan Pengukuran Kesegaran Jasmani Berbasis Mobile Learning
}

\author{
${ }^{1}$ Maulidin, Zul Anwar, dan Hastuti Diah Ikawati \\ ${ }^{1}$ Universitas Pendidikan Mandalika \\ Coresponding Autor: maulidin12@undikma.ac.id
}

\begin{abstract}
Abstrak: Penelitian dan pengembangan ini bertujuan untuk mengembangkan sumber belajar matakuliah tes dan pengukuran olahraga materi tes dan pengukuran kesegaran jasmani. Penelitian ini diawali dengan analisis kebutuhan dengan metode survey dan kemudaian mengembangkan sumber belajar dengan karakteristik sesuai dengan hasil analisis kebutuhan. Pengembangan sumber belajar ini menghasilkan produk berupa aplikasi tes dan pengukuran kesegaran jasmani yang dikemas dalam bentuk *apk yang bisa di install dalam handphone berbasis android. Metode penelitian yang digunakan adalah metode penelitian dan pengembangan dengan langkah-langkah pengembangan yang dirancang oleh Borg dan Gall. Tentunya metode tersebut dimodifikasi oleh peneliti sesuai kebutuhan penelitian. Subjek dari penelitian ini adalah mahasiswa Pendidikan kepelatihan Olahraga yang sedang memperoleh matakuliah tes dan pengukuran kesegaran jasmani sebanyak 35 mahasiswa. Berdasarkan data analisis kebutuhan diperoleh hasil bahwa $100 \%$ mahasiswa membutuhkan pengembangan sumber belajar ini. Sedangkan menurut hasil evaluasi ahli tes dan pengukuran olahraga diperoleh rata-rata skor sebesar 3,58 yang artinya sangat baik dengan persentase sebesar $89,44 \%$, menurut ahli teknologi pembelajaran diperoleh rata-rata skor sebesar 3,56 yang artinya sangat baik dengan persentase sebesar 89,34\%, ahli pembelajaran diperoleh rata-rata skor sebesar 3,67 yang artinya sangat baik dengan persentasenya $91,67 \%$. Hasil uji coba kelompik kecil memperoleh rata-rata skor 3,26 yang artinya baik dengan persentase $80,09 \%$, sedangkan hasil uji coba kelompok besar diperoleh rata-rata skor sebesar 3,57 yang artinya sangat baik dengan persentase $87,96 \%$.
\end{abstract}

Kata Kunci: Sumber Belajar, Tes dan Pengukuran Kesegaran Jasmani, Mobile Learning

\section{Physical Fitness Test Resources Mobile Based Learning Development}

\author{
Maulidin ${ }^{1}$ \\ 1Universitas Pendidikan Mandalika \\ Coresponding Autor: maulidin12@undikma.ac.id
}

\begin{abstract}
The research and development aims to develop learning resources subject matter of sport test and measurement, specifically physical fitness test. This study begins with a needs analysis survey method and than develop learning resources with the characteristics according to the results of the needs analysis. This resulted in the development of learning resources such as product application and measurement of physical fitness tests are packaged in the form of * apk that can be installed in mobile phones based on Android. The method used is a method of research and development with the development steps designed by Borg and Gall. Obviously the method is modified by the researchers as needed research. The subject of this study is the education of students who are obtaining sports coaching course tests and measurements of physical fitness as many as 35 students. Based on the analysis of the data showed that the needs of $100 \%$ of students require the development of this learning resource. Meanwhile, according to the results of the test and measurement expert evaluation of sport gained an average score of 3.58 , which means very good with a percentage of $89.44 \%$, according to instructional technology experts gained an average score of 3.56 , which means very good with a percentage of $89.34 \%$, learning experts obtained an average score of 3.67, which means very good with a percentage of $91.67 \%$. Kelompik small trial results gained an average score of 3.26 , which means well with the percentage of $80.09 \%$, while the results of testing a large group gained an average score of 3.57 , which means very good with a percentage of $87.96 \%$.
\end{abstract}

Keywords: Learning Resources, Physical Fitness Test, Mobile Learning 


\section{A. PENDAHULUA}

Pendidikian yang dilaksanakan di sekolah dan perguruan tinggi seiring dengan berjalannya waktu, terus mengalami perubahan. Kemajuan teknologi informasi dan komunikasi (TIK) menjadi salah satu faktor perubahan dalam sistem pendidikan di Indonesia. Teknologi mempunyai peran yang sangat penting bagi proses pendidikan serta ikut memberikan arah dalam perkembangan dunia pendidikan. Dalam sejarah perkembangan pendidikan, teknologi informasi adalah bagian dari media yang digunakan untuk menyampaikan pesan ilmu pada orang banyak, mulai dari teknologi percetakan beberapa abad yang lalu, seperti buku yang dicetak, hingga media telekomunikasi seperti, suara yang direkam pada kaset, video, televisi, $\mathrm{CD}$ dan pembelajaran melalui internet (e-learning).

Sumber belajar merupakan salahsatu komponen dalam proses pembelajaran yang memiliki peranan penting dalam mencapai tujuan pembelajaran. Seperti yang diungkap dalam UU sisdiknas tahun 2003 yang menyatakan bahwa pembelajaran adalah proses interaksi antara pendidik, peserta didik dan sumberbelajar didalam lingkungan belajar tertentu (KKNI, 2012).

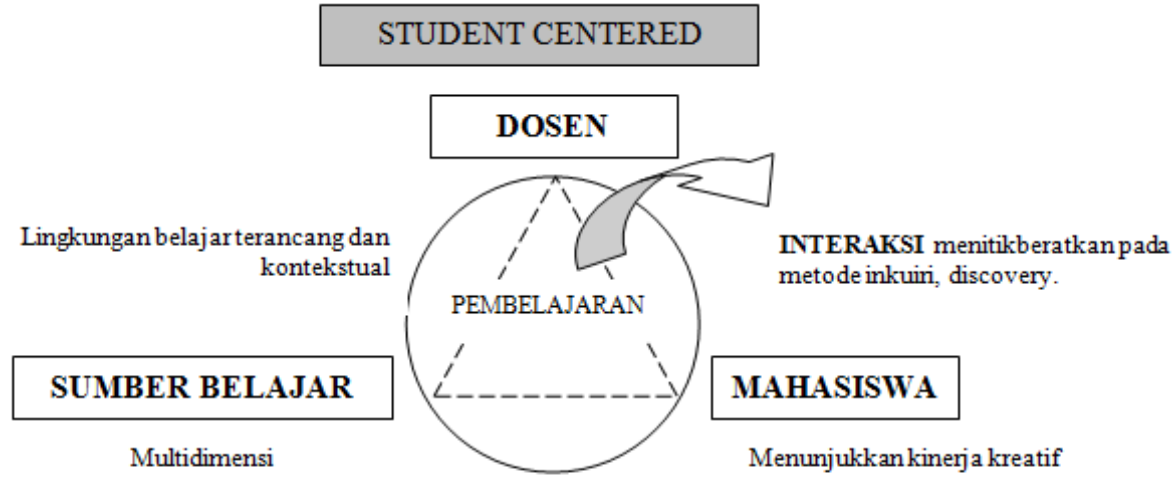

Gambar 2.3 Proses interaksi dalam pembalajaran

(Sumber: KKNI, 2008)

Allison (2008, 752-771) mengatakan bahwa, "learning resources are fundamental to good quality education; print based resources are well established as an integral part of teaching across all sectors of education and their use has evolved over a long period of time, especially in conventional, didactic modes of teaching".

Sumber belajar memiliki peranan penting dalam mencapai kualitas pendidikan yang bermutu. Sumber belajar dalam bentuk teknologi cetak telah menjadi bagian integral sistem pendidikan dalam waktu yang lama untuk mencapai tujuan pendidikan terutama dalam sistem pendidikan konvensional.

Mobile learning (m-learning) adalah isu hangat yang berkembang dalam pengembangan bahan ajar sejak dari tahun 2000-an. Mobile learning memanfaatkan perangkat mobile seperti smartphone (termasuk golongan cell phone) dalam menunjang pembelajaran. Mempermudah akses sumber belajar serta menjadikan sumber belajar lebih menarik. Mobile learning memiliki tingkat fleksibilitas yang tinggi dalam hal kemudahan akses. Materi yang dipersiapkan pendidik untuk memfasilitasi peserta didik belajar mandiri bisa dikemas dalam bentuk teks, audio dan video dalam satu perangkat smartphone. Dengan demikian proses transfer pengetahuan melalui interaksi antara peserta didik dengan sumber belajar menjadi semakin mudah.

M-learning merupakan pembelajaran yang memanfaatkan teknologi informasi dan komunikasi. m-learning memberikan kemudahan akses materi dengan memperkaya sumber belajar yang variatif dengan visualisasi materi yang menarik. Berikut definisi beberapa ahli terkait dengan m-learning (Gary, 2011): 
O'Malley et al. (2003) said that mobile learning is “. . . any sort of learning that happens when the learner is not at a fixed, predetermined location, or learning that happens when the learner takes advantage of learning opportunities offered by mobile technologies. "This is similar to John Traxler's (2005) definition that mobile learning is “. . . any educational provision where the sole or dominant technologies are handheld or palmtop devices." Keegan (2005) tried to define mobile learning by the size of the mobile device: "Mobile learning should be restricted to learning on devices which a lady can carry in her hand-bag or a gentle-man can carry in his pocket. "Geddes (2004) defined mobile learning as "the acquisition of any knowledge and skill through using mobile technology, anywhere, anytime, that results in an alteration in behaviour".

Matakuliah tes dan pengukuran adalah salahsatu matakuliah yang harus ditempuh oleh mahasiswa program studi pendidikan olahraga. Dengan beban 3 sks tentu matakuliah ini memiliki tingkat kesukaran yang tidak bisa dibilang mudah. Matakuliah ini meliputi kemampuan teoritik dan praktik. Cukup banyak jenis tes dan pengukuran olahraga salahsatunya adalah tes dan pengukuran kesegaran jasmani seseorang. Tes dan pengukuran kesegaran jasmani merupakan salahsatu materi yang diajarkan dalam matakuliah tes dan pengukuran olahraga. Tes dan pengukuran kesegaran jasmani dapat dibagi menjadi beberapa komponen yang terbagi dalam dua aspek kesegaran jasmani yaitu: (1) kesegaran jasmani yang berhubungan dengan kesehatan, antara lain: (a) daya tahan jantung dan paru, (b) kekuatan otot, (c) dayatahan otot, (d) fleksibilitas, dan (e) komposisi tubuh. (2) kesegaran jasmani yang berhubungan dengan keterampilan, yaitu: (a) kecepatan, (b) power, (c) keseimbangan, (d) kelincahan, (e) koordinasi, dan (f) kecepatan reaksi (Widiastuti, 2011).

Sumber belajar yang selama ini digunakan adalah teknologi cetak (buku) dan beberapa telah menggunakan e-learning kesegaran jasmani (multimedia interaktif) dengan menggunakan bantuan komputer. Sumber belajar yang tersedia sementara ini cukup memadai, namun dengan memanfaatkan perkembangan teknologi, setidaknya peneliti berusaha untuk terus meningkatkan kesempatan belajar yang lebih fleksibel tidak terbatasi oleh waktu dan ruang tertentu. Oleh karena itu penulis mencoba untuk terus mengembangkan bentuk sumber belajar yang lebih mudah di akses, salah satunya adalah dengan menggunakan mobile learning.

Sumber belajar berbasis m-learning dipilih dengan pertimbangan bahwa semakin mudahnya masyarakat mendapatkan perangkat smartphone dengan harga yang semakin terjangkau dibandingkan harga komputer atau laptop. Tingkat fleksibilitas akses sumber belajar semakin tinggi. Serta perangkat smartphone yang telah memiliki aplikasi yang menunjang pengembangan sumber belajar ini yaitu software Java (sudah terpasang pada mayoritas hp android).

\section{B. METODE}

Penelitian ini menggunakan pendekatan penelitian dan pengembangan. Sedangkan model pengembangan yang digunakan adalah model pengembangan Research \& Development (R \& D) dari Borg dan Gall yang terdiri dari sepuluh langkah antara lain (Borg\&Gall, 1983):

(1 Melakukan penelitian dan pengumpulan informasi (kajian pustaka, pengamatan subyek, persiapan laporan pokok persoalan) (2) Melakukan perencanaan (pendefinisian keterampilan, perumusan tujuan, penentuan urutan pengajaran, dan uji coba skala kecil) (3) Mengembangkan bentuk produk awal (penyiapan materi pengajaran, penyusunan buku pegangan, dan perlengkapan evaluasi) (4) Melakukan uji lapangan permulaan (menggunakan 6-12 subyek) (5) Melakukan revisi terhadap produk utama (sesuai dengan saran-saran dari hasil uji lapangan permulaan) (6) Melakukan uji lapangan utama (dengan 30-100 subyek. (7) Melakukan revisi produk (berdasarkan saran-saran dan hasil uji coba lapangan utama). (8) Uji lapangan dengan 40-200 subyek (9) Revisi produk akhir (10) Membuat laporan mengenai 
produk pada jurnal, bekerja dengan penerbit yang dapat melakukan distribusi secara komersial.

Sedangkan untuk mengembangkan sumber belajar, pada langkah ketiga Borg dan Gall, menggunakan model pengembangan multimedia oleh sutopo yang terdiri dari concept, design, material collecting, assembly, testing, distribution.

Sumber belajar tes dan pengukuran kesegaran jasmani ini dikembangkan dengan menggunakan langkah pengembangan Borg dan Gall dan langkah rancangan pengembangan produk multimedia oleh sutopo. Pada setiap tahap penelitian dan pengembangan ini terdapat langkah-langkah rancangan yang penjelasannya diuraikan dan dimodifikasi sesuai dengan tujuan dan kondisi penelitian yang sebenarnya. Berikut ini adalah rencana pengembangan model.

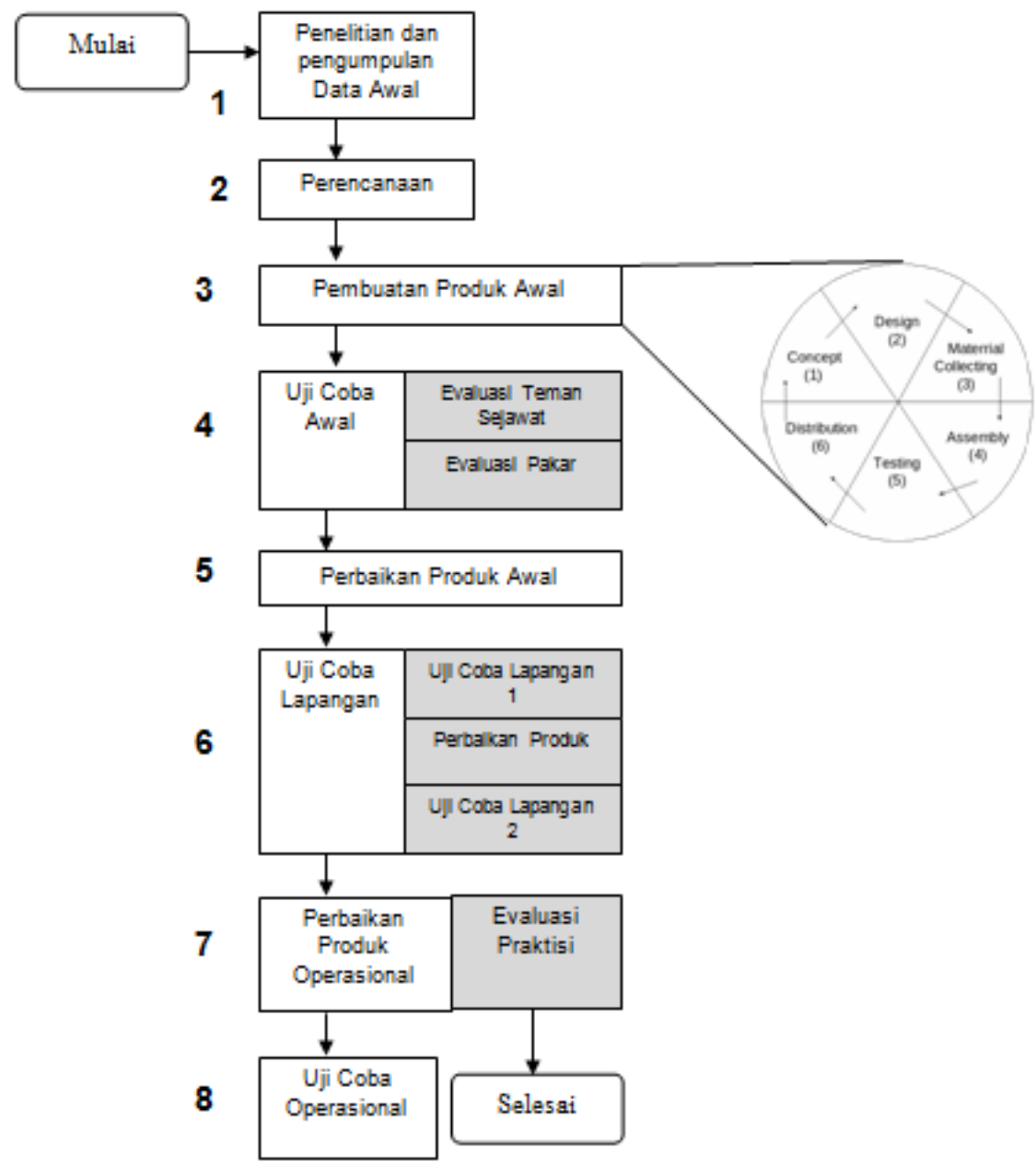

Gambar 3.1. Alur rencana pengembangan model

Alur yang tergambarkan di atas merupakan alur yang telah dimodifikasi oleh peneliti. Alur yang digunakan disesuaikan dengan kondisi lapangan yang sebenarnya. Dengan mempertimbangkan ketersediaan waktu dan dana maka pada beberapa langkah akan dimodifikasi namun tidak keluar dari alur yang dipilih. Alur tersebut adalah alur penelitian dan pengembangan oleh Borg dan Gall serta dikombinasikan dengan pengembangan multimedia oleh Sutopo. Berikut ini adaah penjabaran masing-masing rencana pengembangan model: 
1. Melakukan penelitian dan pengumpulan data untuk penelitian awal atau analisis kebutuhan (need assement) terhadap 30 mahasiswa yang pernah mengikuti Mata Kuliah Teori dan Praktik tes dan pengukuran olahraga.

2. Perencanaan pengembangan dilakukan dengan menentukan tujuan, membatasi ruang lingkup, dan mempersiapkan rencana uji coba.

3. Mengembangkan produk awal, yang selajutnya dievaluasi oleh 1 ahli media, 1 ahli tes dan pengukuran olahraga, 1 ahli pembelajaran dan melakukan revisi produk.

4. Uji coba kelompok kecil, menggunakan 10 subjek mahasiswa yang pernah mengikuti Mata Kuliah Teori dan Praktik tes dan pengukuran olahraga.

5. Revisi produk (sesuai dengan hasil analisis pada uji coba kelompok kecil).

6. Uji coba lapangan (kelompok besar) menggunakan 30 subjek mahasiswa yang pernah mengikuti Mata Kuliah Teori dan Praktik tes dan pengukuran olahraga. Jika dalam penelitian yang dianjurkan oleh Borg dan Gall, pada tahap ini diperlukan uji coba dalam skala besar (makro) yaitu setidaknya meliputi 30 atau lebih subyek di 200 sekolah, namun dalam penelitian ini dengan pertimbangan waktu dan biaya, maka akan dilaksanakan terbatas di satu tempat yaitu di Jurusan Pendidikan Jasmani dan Kesehatan Universitas Negeri Malang dengan jumlah responden 30 atau lebih.

7. Melakukan revisi produk sesuai hasil uji coba kelompok besar.

8. Melakukan uji coba operasional untuk mengetahui efektifitas produk.

Sedangkan untuk perancangan produk pengembangan sumber belajar berbasis mobile learning dikutip dari sutopo dengan enam tahapan pengembangan produk multimedia yaitu concept, design, material collecting, assembly, testing, distribution (Sutopo, 2003). Berikut adalah penjelasan masing-masing tahapannya:

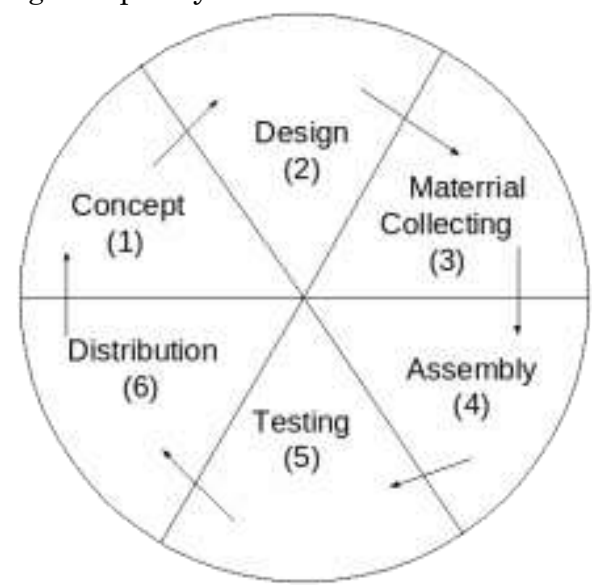

Gambar 3. 2. Tahap pengembangan multimedia interaktif

(Sumber, Sutopo, 2003)

Berikut adalah penjelasan, masing-masing langkah:

1. Concept. Pada tahap ini, peneliti menentukan tujuan pengembangan produk dan mengidentifikasi pengguna (target client). Tujuan utama pengembangan mobile learning tes dan pengukuran kesegaran jasmani ini adalah untuk menambah literasi belajar bagi mahasiswa. Selain itu mobile learning ini memberikan kemudahan akses materi tes dan pengukuran kebugaran jasmani, memungkinkan mahsiswa belajar tanpa terhalang oleh ruang dan waktu. Produk ini sengaja disesuaikan dengan gaya hidup mahasiswa yang semakin dekat dengan handphone karena produk akhir dari pengembangan mobile learning ini akan digunakan oleh mahasiswa.

2. Design. Rancangan produk mobile learning kesegaran jasmani ini dikemas dalam bentuk softfile berformat "*.apk". produk mobile learning ini dilengkapi dengan text, gambar, dan 
animasi yang menarik. Perancangan produk menggunakan aplikasi ispring suite presentation dan andaired.

3. Material Collecting. Pada tahap pengumpulan bahan pembuatan produk ini, peneliti mengumpulkan bahan yang dibutuhkan, antara lain adalah materi tes dan penngukuran kesegaran jasmani dalam bentuk buku teks, aplikasi ispring suite presentation, aplikasi andaired, gambar yang sengaja dirancang sesuai dengan bentuk tes (ilustrasi gambar), program dan flowcart.selain itu dibutuhkan smartphone untuk ujicoba awal.

4. Assembly. Tahap assembly (pembuatan) pada tahapan ini materi dalam bentuk text, akan digabungkan dengan gambar dan animasi dengan bantuan aplikasi ispring suite presentation. kemudian akan di export dalam bentuk soft file “".apk" menggunakan aplikasi andaired.

5. Testing. Setelah produk berhasil di buka menggunakan smartphone. Akan di operasikan, selama pengoperasian akan di amati berbagai kendala dan kekurangan jyang muncul serta direncanakan perbaikannya.

6. Distribution. Setelah di operasikan dan menunjukkan hasil yang baik,produk akan disimpan dalam bentuk softfile berformat *apk dalam SD card smartphone. Dengan demikian maka akan lebih mudah untuk didistribusikan.

\section{HASIL}

Hasil pengembangan sumber belajar tes dan pengukuran kesegaran jasmani berbasis mobile learning ini adalah produk dalam bentuk softfile berformat * apk yang diinstal dalam smartphone android. Sumber belajar ini meliputi, text, gambar dan scribt analisis skor kesegaran jasmani.

Dari hasil analisis kebutuhan, ada beberapa poin penting yang menjadikan kunci perlunya pengembangan dilakukan. Antara lain adalah, bawa 1) dari 35 mahasiswa 100\% mahasiswa mendapatkan matakuliah tes dan pengukuran olahraga, 2) dari 35 mahasiswa $100 \%$ mahasiswa masih belum menguasai materi tes dan pengukuran kesegaran jasmani, 3) dari 35 mahasiswa 100\% menyatakan bahwa dosen belum menggunakan sumber belajar berbasis mobile learning, 4) dari 35 mahasiswa 86\% mahasiswa memiliki handphone dengan sistem operasi android (smartphone), 5) dari 35 mahasiswa 100\% sependapat bahwa smartphone android berpotensi dijadikan sebagai sumber belajar, 6) dari 35 mahasiswa 100\% setuju jika diadakan pengembangan sumber belajar tes dan pengukuran kesegaran jasmani berbasis mobile learning, 7) dari 35 mahasiswa 100\% menyatakan bahwa bersedia menggunakan sumber belajar tes dan pengukuran kesegaran jasmani berbasis mobile learning.

Kelayakan produk di lakukan dengan cara uji ahli untuk memberikan penilaian dan masukan sehingga memenuhi kriteria layak secara teoritik dan empiris. Berdasarkan data dan tanggapan yang berhasil dikumpulkan dari ahli teknologi pembelajaran, ahli tes dan pengukuran, dan ahli pembelajaran pendidikan jasmani, maka ada beberapa bagian produk yang perlu direvisi. Hal ini dilakukan untuk lebih mengoptimalkan manfaat pengembangan bagi mahasiswa.

Evaluasi terhadap hasil pengembangan Sumber belajar tes dan pengukuran kesegaran jasmani berbasis mobile learning oleh ahli teknologi pembelajaran adalah sebagai berikut :

1. Ukuran font pada menu petunjuk, profil dan semua menu materi masih terlalu kecil sehingga perlu di rubah.

2. Frame untuk text dan gambar pada menu intro dan semua menu dalam materi masih bisa dilebarkan.

3. Font yang digunakan sebaiknya font yang mudah dibaca seperti "arial"

4. Gambar diganti dengan resolusi tinggi supaya tidah kabur.

5. Button exit tidak berfungsi. 
Evaluasi terhadap hasil pengembangan sumber belajar tes dan pengukuran kesegaran jasmani oleh ahli tes dan pengukuran adalah sebagai berikut :

1. Kejelasan hurus pada semua menu terlalu kecil sehingga keterbacaannya menjadi sulit.

2. Pada petunjuk penggunaan sebaiknya disertai dengan penjelasan singkat dan keterangan subyek pengguna.

3. Kuis yang disediakan sebaiknya lebih dari satu jenis.

Evaluasi terhadap hasil pengembangan sumber belajar tes dan pengukuran kesegaran jasmani berbasis mobile learning oleh ahli pembelajaran pendidikan jasmani adalah tidak ada revisi.

Hasil uji coba kelompok kecil Sumber belajar tes dan pengukuran kesegaran jasmani berbasis mobile learning memperoleh skor 3,26 yang artinya rata-rata baik dengan persentese 81,09 dengan kategori valid, sehingga bisa dilanjutkan ke uji coba kelompok besar.

Hasil uji coba kelompok besar Sumber belajar tes dan pengukuran kesegaran jasmani berbasis mobile learning memperoleh skor 3,57 yang artinya rata-rata sangat baik dengan persentese 87,96 dengan kategori valid sehingga produk bisa digunakan.

Berikut ini disajikan hasil analisis data kelayakan produk dari para ahli:

\section{Analisis Data dari Ahli Teknologi Pembelajaran}

Berdasarkan hasil analisis evaluasi ahli teknologi pembelajaran diketahui bahwa jumlah skor maksimal $\left(\sum \mathrm{X}\right)$ adalah 608 dan jumlah skor yang diperoleh ( $\left.\sum \mathrm{X} 1\right)$ adalah 555. Sehingga, persentasenya adalah $89,34 \%$.

Berdasarkan hasil analisis yang telah dilakukan terhadap tanggapan/penilaian dari ahli teknologi pembelajaran, hasilnya adalah $\mathbf{8 9 , 3 4} \%$, dari kriteria yang ditentukan dan dapat dikatakan bahwa sumber belajar tes dan pengukuran kesegaran jasmani berbasis mobile learning ini memenuhi kriteria VALID (80\% - 100\%) sehingga dapat digunakan dan dipraktekkan dalam pelaksanaan tes dan pengukuran kesegaran jasmani.

\section{Analisis Data dari Ahli tes dan pengukuran kesegaran jasmani}

Berdasarkan hasil analisis evaluasi ahli tes dan pengukuran olahraga diketahui bahwa jumlah skor maksimal $\left(\sum \mathrm{X}\right)$ adalah 288 dan jumlah skor yang diperoleh $\left(\sum \mathrm{X} 1\right)$ adalah 255. Sehingga, persentasenya adalah $89,44 \%$.

Berdasarkan hasil analisis yang telah dilakukan terhadap tanggapan/penilaian dari ahli tes dan pengukuran olahraga, hasilnya adalah $\mathbf{8 9 , 4 4} \%$, dari kriteria yang ditentukan dan dapat dikatakan bahwa sumber belajar tes dan pengukuran kesegaran jasmani berbasis mobile learning ini memenuhi kriteria VALID (80\% - 100\%) sehingga dapat digunakan dan dipraktekkan dalam pelaksanaan tes dan pengukuran kesegaran jasmani.

\section{Analisis Data dari Ahli Pembelajaran Pendidikan Jasmani}

Berdasarkan hasil analisis evaluasi ahli pembelajaran diketahui bahwa jumlah skor maksimal $\left(\sum \mathrm{X}\right)$ adalah 48 dan jumlah skor yang diperoleh $\left(\sum \mathrm{X} 1\right)$ adalah 44 . Sehingga, persentasenya adalah $91,67 \%$.

Berdasarkan hasil analisis yang telah dilakukan terhadap tanggapan/penilaian dari ahli pembelajaran, hasilnya adalah 91,67 \%, dari kriteria yang ditentukan dan dapat dikatakan bahwa sumber belajar tes dan pengukuran kesegaran jasmani berbasis mobile learning ini memenuhi kriteria VALID (80\% - 100\%) sehingga dapat digunakan dan dipraktekkan dalam pelaksanaan tes dan pengukuran kesegaran jasmani.

\section{Data peningkatan pemahaman tes dan pengukuran kesegaran jasmani}

Untuk mengetahui efektifitas produk berupa sumber belajar tes dan pengukuran kesegaran jasmani berbasis mobile learning yang di uji cobakan kepada para mahasiswa apakah sudah berhasil atau belum, maka ada data yang harus dikumpulkan, yaitu data tentang kemampuan kognitif mahasiswa dalam menguasai materi tes dan pengukuran kesegaran jasmani. Pengumpulan data ini dilakukan setelah uji kelompok besar/ uji coba lapangan 2. Pengumpulan data efisiensi produk ini dilakukan dengan cara membandingkan rata-rata nilai kognitif mahasiswa yang menggunakan sumber belajar konvensional/ buku 
dengan mahasiswa yang menggunakan sumber belajar tes dan pengukuran kesegaran jasmani berbasis mobile learning. Berikut akan di sajikan data-data tersebut secara ringkas:

\section{1) Data Nilai Kognitif}

Data nilai kognitif dari subjek pada uji coba kelompok besar dapat dilihat pada tabel berikut:

Tabel 4.8 Data Perbandingan Nilai Kognitif Mahasiswa Yang Menggunakan Sumber Belajar Buku Text Dan Mahasiswa Yang Menggunakan Mobile Learning Tes Dan Pengukuran Kesegaran Jasmani

\begin{tabular}{|c|c|c|c|}
\hline $\begin{array}{c}\text { Responden Menggunakan } \\
\text { Buku Text }\end{array}$ & Nilai & Nilai & $\begin{array}{c}\text { Responden menggunakan } \\
\text { Mobile learning }\end{array}$ \\
\hline 1 & 65 & 70 & 1 \\
\hline 2 & 100 & 70 & 2 \\
\hline 3 & 75 & 95 & 4 \\
\hline 4 & 100 & 90 & 5 \\
\hline 5 & 90 & 55 & 6 \\
\hline 6 & 90 & 95 & 7 \\
\hline 7 & 85 & 70 & 8 \\
\hline 8 & 80 & 75 & 9 \\
\hline 9 & 80 & 80 & 10 \\
\hline 10 & 65 & 100 & 11 \\
\hline 11 & 75 & 90 & 12 \\
\hline 12 & 55 & 70 & 14 \\
\hline 13 & 75 & 90 & 15 \\
\hline 14 & 65 & 75 & Rata-rata Nilai \\
\hline 15 & 60 & 50 & $\mathbf{7 8 . 3 3}$ \\
\hline
\end{tabular}

Berdasarkan tabel data nilai kognitif di atas, diperoleh hasil rata-rata nilai responden yang menggunakan buku text adalah 77,33 sedangkan responden yang, menggunakan mobile learning adalah 78,33, dengan demikian dapat disimpulkan bahwa responden yang menggunakan mobile learning tes dan pengukuran kesegaran jasmani memiliki nilai lebih baik dibandingkan dengan yang menggunakan buku text.

\section{KESIMPULAN}

Berdasarkan data yang diperoleh, dari hasil uji coba lapangan dan pembahasan hasil penelitian dapat disimpulkan bahwa:

1. Dengan adanya sumber belajar tes dan pengukuran berbasis mobile learning ini mahasiswa dapat mempelajari dan melaksanakan tes dan pengukuran kesegaran jasmani secara efektif dan efisien.

2. Dengan adanya sumber belajar tes dan pengukuran berbasis mobile learning ini mahasiswa dapat menguasai materi teori dan praktik tes dan pengukuran kesegaran jasmani dengan cepat dan benar.

\section{E. DAFTAR PUSTAKA}

1. A. Lilttlejohn et al. 2008. Characterising Effective eLearning resources. (United Kingdom: Elsevier, 2008)

2. Borg. W. R \& Gall, M. D, Educational Research An Introduction (New York : Longman, 1983)

3. Gary. Woodille.. Mobile Learning. (US; The Mc Graww-Hill Companies, 2011).

4. Kerangka Kualifikasi Nasional Indonesia (KKNI). (Jakarta: Kemendikbud, 2012) 
5. Widiastuti. Tes dan Pengukuran Olahraga. (Jakarta: PT Bumi Timur Jaya, 2011)

6. Sutopo, Ariesto Hadi. Multimedia Interaktif dengan Flash. (Yogyakarta: Graha Ilmu, 2003) 